\title{
AMYLASE PRODUCTION BY SOLID-STATE FERMENTATION OF AGRO-INDUSTRIAL WASTES USING BACILLUS SP.
}

\author{
Rajshree Saxena ${ }^{1}$, Rajni Singh ${ }^{2} *$ \\ ${ }^{1}$ Amity Institute of Biotechnology, Amity University, Sector-125, Noida, Uttar Pradesh, India; ${ }^{2}$ Amity Institute of Microbial \\ Biotechnology, Amity University, Sector-125, Noida, Uttar Pradesh, India.
}

Submitted: July 21, 2009; Approved: June 06, 2011.

\begin{abstract}
Solid state fermentation was carried out using various agro- industrial wastes with the best amylase producing strain isolated from soil. Different physicochemical conditions were varied for maximum enzyme production. The strain produced about 5400 units/g of amylase at 1:3 moisture content, $20 \%$ inoculum, after $72 \mathrm{~h}$ of incubation with Mustard Oil seed cake as the substrate. The optimum temperature and $\mathrm{pH}$ of the enzyme activity were found to be $50^{\circ} \mathrm{C}$ and 6 respectively. The enzyme was found to be thermostable at $70^{\circ} \mathrm{C}$ for about $2 \mathrm{~h}$ without any salt. It showed stability at $\mathrm{pH}$ range $5-7$. The metal ions as $\mathrm{Na}^{+}, \mathrm{Ca}^{++}, \mathrm{Mg}^{++}$ and $\mathrm{Co}^{++}$enhanced the enzyme activity.
\end{abstract}

Key words: Solid State Fermentation, Agro-industrial wastes, Amylase, Enzyme optimization, Stability, Bacillus sp.

\section{INTRODUCTION}

Amylase is one of the most widely used enzymes in the industry. It hydrolyses starch and is used commercially for the production of sugar syrups from starch which consist of glucose, maltose, and higher oligosaccharides (10). Amylases are of great significance in biotechnological applications ranging from food, fermentation, detergent, pharmaceutical, brewing and textile to paper industries $(18,12)$. To meet the higher demands of these industries, low cost production of amylase is required.

Amylase is produced in bacteria, fungi, plants and animals. However, due to efficient production strategies, microorganisms have substantial potential to contribute to a number of industrial applications (23). Such industrially important microorganisms are found within the Bacillus species because of their rapid growth rates that lead to short fermentation cycles, their capacity to secrete proteins into extra cellular medium, and general handling safety (19).

Production of these $\alpha$ amylases has been investigated through submerged $(\mathrm{SmF})$ and solid-state fermentation (SSF) (21). However, the contents of a synthetic medium are very expensive and uneconomical, so they need to be replaced with more economically available agricultural and industrial byproducts, as they are considered to be good substrates for SSF to produce enzymes (17). In recent years the technique of 
solid-state fermentation (SSF) process has been developed and used more extensively. It has advantages over SmF like simple technique, low capital investment, cheaper production of enzyme having better physiochemical properties, lower levels of catabolite repression and better product recovery (5). The major factors that affect microbial synthesis of enzymes in a SSF system include selection of a suitable substrate and microorganism, particle size of the substrate, inoculum concentration and moisture level of the substrate. Thus it involves the screening of a number of agro-industrial materials for microbial growth and product formation (23). Temperature and $\mathrm{pH}$ are known to be important parameters in the production of enzymes from bacteria; hence, the thermal and the $\mathrm{pH}$ stability of the enzyme, which is a function of the exposure time, must also be taken into account.

The present work represents an investigation into amylase production by SSF with Wheat bran, Gram husk, Rice Bran and Mustard Oilseed cake as substrates and the determination of optimized production conditions.

\section{MATERIALS AND METHODS}

\section{Isolation of Bacteria}

About 50 strains were isolated from soil samples collected from various sites at Delhi and NCR, India. These strains were characterized by colony morphologically, shape and gram character; and maintained in $50 \%$ glycerol stock at $-20^{\circ} \mathrm{C}$ till further use.

\section{Screening of bacterial isolates}

Primary screening of bacterial isolates for production of alpha amylase was done by the starch agar plate method (2). Out of 50 strains, the 3 strains that showed the biggest zone of clearance in starch hydrolysis were selected for production in Solid State Fermentation.

Inoculum preparation: The selected bacterial strains were inoculated in nutrient broth [consisting of $\left(\mathrm{g} \mathrm{L}^{-1}\right)$ : peptone, 5; Beef extract, $3 ; \mathrm{NaCl}, 5]$ followed by incubation at $37^{\circ} \mathrm{C}$ for $24 \mathrm{~h}$ to get a standardized inoculum $(0.5 \mathrm{OD}$ at $600 \mathrm{~nm}$ with $\left.3.5 \times 10^{5} \mathrm{cfu} / \mathrm{ml}\right)$

\section{Substrate}

Four different types of agro-industrial wastes to be used as substrate viz., Wheat bran, Gram husk, Rice Bran and Mustard Oilseed cake were procured from local market of Delhi and powdered obtain a particle size of 1.0 to $2.0 \mathrm{~mm}$. SSF was performed with all the four substrates and their enzyme production was checked by assay.

\section{SSF Technique}

Experiments were conducted in $100 \mathrm{ml}$ Erlenmeyer flasks containing $5 \mathrm{~g}$ of the substrate impregnated with $10 \mathrm{ml}$ of sterile liquid nutrient medium containing(\%): $\left[\mathrm{KH}_{2} \mathrm{PO}_{4}-0.1, \mathrm{NaCl}-\right.$ $\left.0.25, \mathrm{MgSO}_{4} .7 \mathrm{H}_{2} \mathrm{O}-0.01, \mathrm{CaCl}_{2}-0.01\right]$. The flasks were autoclaved and inoculated with $1 \mathrm{ml}$ of the prepared inoculum, thoroughly mixed and followed by incubation at $37^{\circ} \mathrm{C}$ for 5 days. Samples were aseptically withdrawn periodically and assayed for amylase activity.

\section{Enzyme assay}

Estimation of amylase activity was carried out according to the DNSA (3, 5 dinitro salicylic acid) method. One $\mathrm{ml}$ of $1 \%$ starch was incubated with different dilutions of the enzyme extract and $1 \mathrm{ml}$ of citrate- phosphate buffer $(\mathrm{pH} 6.0)$. The reaction mixture was incubated at $50^{\circ} \mathrm{C}$ for $30 \mathrm{~min}$. The reaction was stopped by adding $2 \mathrm{ml}$ of DNS and kept in boiling water bath for $10 \mathrm{~min}$. The absorbance was read at 540nm using a Spectrophotometre (Shimadzu, Thermoelectric cell holder,S-1700), against glucose as the standard. One unit of enzyme activity is defined as the amount of enzyme, which releases $1 \mu$ mole of reducing sugar as glucose per minute, under the assay conditions $(\mathrm{U} / \mathrm{ml} / \mathrm{min})$. The experiments were carried out in triplicates and standard error was calculated.

\section{Optimization studies for enzyme production}

In a sequential order, the various physicochemical factors as substrate, moisture content and inoculum size affecting the enzyme production were optimized for maximal enzyme 
production by using the solid substrate for which best amylase activity was observed.

\section{Substrate}

The enzyme production was studied with all the four types of agro-industrial wastes viz., Wheat bran, Gram husk, Rice Bran and Mustard Oilseed cake.

\section{Moisture}

Moisture content for the solid state fermentation of the enzyme was evaluated by varying the moisture content from $1: 2,1: 3,1: 4$ and $1: 5$.

\section{Inoculum Size}

The enzyme production was checked by varying the inoculum size at $1 \%, 5 \%, 10 \%$ and $20 \%$ of bacterial culture with colony count at $3.5 \times 10^{5} \mathrm{cfu} / \mathrm{ml}$.

\section{Partial purification of enzyme}

Partially purified enzyme was obtained by addition of solid $\left(\mathrm{NH}_{4}\right)_{2} \mathrm{SO}_{4}$ to the crude enzyme obtained after solid state fermentation, with constant stirring at room temperature. The precipitate was collected by centrifugation at $12000 \mathrm{x}$ g for 20 $\min$ at $4^{\circ} \mathrm{C}$. This precipitate was dissolved in $0.1 \mathrm{M}$ phosphate buffer ( $\mathrm{pH}$ 6.0) and dialyzed overnight against the same buffer. This dialysate was used as the enzyme solution.

\section{Evaluation of factors affecting enzyme activity}

Various process parameters as temperature and $\mathrm{pH}$ affecting enzyme activity were optimized. The strategy was to optimize each parameter for the best enzyme activity, independently of the others and subsequently optimal conditions were employed in all experiments.

\section{Temperature Optima}

Optimum temperature for the enzyme assay was assessed by varying the incubation temperature of the assay from $30^{\circ} \mathrm{C}$ to $70^{\circ} \mathrm{C}$.

\section{pH Optima}

Optimum $\mathrm{pH}$ for the enzyme assay was assessed by performing the assay with buffers ranging from $\mathrm{pH} 5$ to 9 (citrate phosphate buffer for $\mathrm{pH}$ 5-8 \& Tris- $\mathrm{HCl}$ buffer for $\mathrm{pH}$ 9).

\section{Thermostability of Amylase}

The thermal stability of the enzyme was assessed by incubating the enzyme without the substrate at various temperatures between 30 to $60^{\circ} \mathrm{C}$ for $2 \mathrm{~h}$. Enzyme was taken at every 30min intervals, and was assayed for activity, thus assessing the stability of the enzyme at different temperatures.

\section{pH stability}

The stability of the enzyme in different $\mathrm{pH}$ was assessed by incubating the enzyme for $2 \mathrm{hrs}$ in buffers of different $\mathrm{pH}$ (citrate phosphate buffer for $\mathrm{pH}$ 5-8 \& Tris-HCl buffer for $\mathrm{pH}$ 9). The stability of the enzyme was investigated by checking the enzyme activity at every $30 \mathrm{~min}$

\section{Effect of Metal Ions}

Enzyme activity was assayed in the presence of $5 \mathrm{mM}$ and $10 \mathrm{mM}$ concentrations of various metal ions $\left(\mathrm{Na}^{+}, \mathrm{Mg}^{++}, \mathrm{Ca}^{++}\right.$ and $\mathrm{Co}^{++}$) in chloride salts. The relative activity of the enzyme was compared with the activity obtained in $0.1 \mathrm{M}$ citrate phosphate buffer.

\section{RESULTS}

Three strains RSA-27, RSB-75 and RSE-162, were selected on the basis of the zone of clearance they exhibited in the starch test, for the SSF technique. Fig 1 shows the enzyme production by these strains in utilizing Wheat bran as substrate in the solid state fermentation.

Strain RSA-27 showed the maximum activity of $900 \mathrm{U} / \mathrm{g}$, while Strain RSB-75 and Strain RSE-162 showed the maximum activity of $200 \mathrm{U} / \mathrm{g}$ and $626 \mathrm{U} / \mathrm{g}$ respectively on the third day. The production in all the three strains increased till 
day 3, where they showed the maximum enzyme activity, thereafter, decreasing substantially till day 5. Hence, strain
RSA-27, a gram positive rod shaped bacterium, was selected for further testing and optimization.

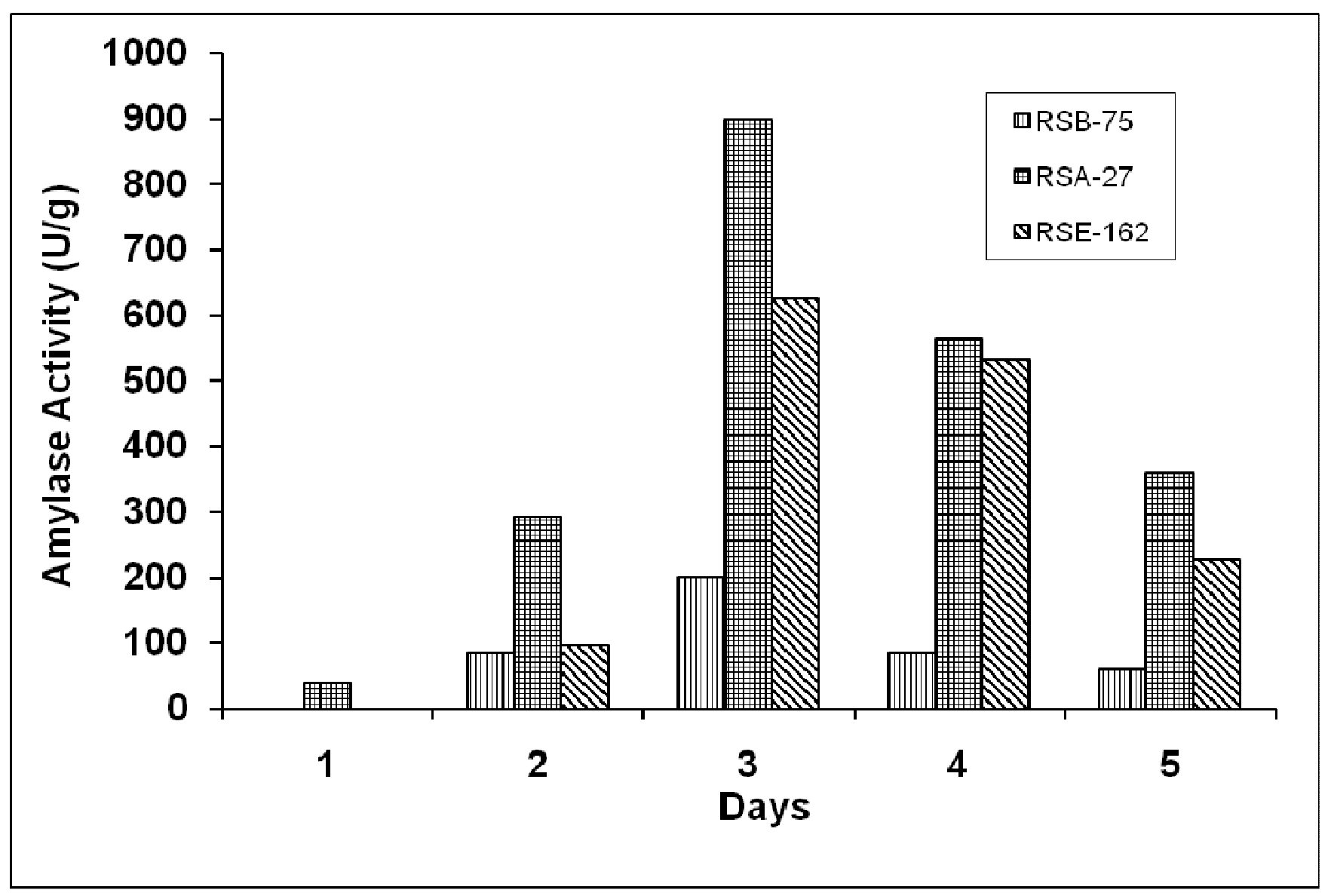

Figure 1. Amylase production by three strains RSB- 75 (四), RSA- 27 (罭) and RSE 162 (目) by using Wheat Bran as substrate.

\section{Effect of different Substrate, Moisture content and} Inoculum size on enzyme production

Fig. 2 shows the enzyme production of the strain with all the four substrates (Wheat Bran, Gram Husk, Rice Bran and Mustard Oilseed cake), the effect of variation in the moisture content and the inoculum size. The best productivity was observed with Mustard Oilseed Cake with which about 5166 $\mathrm{U} / \mathrm{g}$ of enzyme was produced which was much high compared to 1233,900 and $933 \mathrm{U} / \mathrm{g}$ of enzyme produced by using Wheat Bran, Gram Husk, Rice Bran respectively. Hence Mustard

Oilseed Cake was selected as substrate for further optimization.

The best production was given at moisture content 1:3. At 1:3 moisture content, the strain showed an enzyme activity of $5366 \mathrm{U} / \mathrm{g}$ compared to 2966 units, 2166 units and $1233 \mathrm{U} / \mathrm{g}$ at $1: 5,1: 4$ and $1: 2$ ratios respectively.

Similarly, the best inoculum size was found to be $20 \%$ which yielded $5133 \mathrm{U} / \mathrm{g}$ of enzyme on the third day. At $1 \%$, $5 \%$ and $10 \%$ the enzyme production was 226,1733 and 3333 $\mathrm{U} / \mathrm{g}$ respectively. 


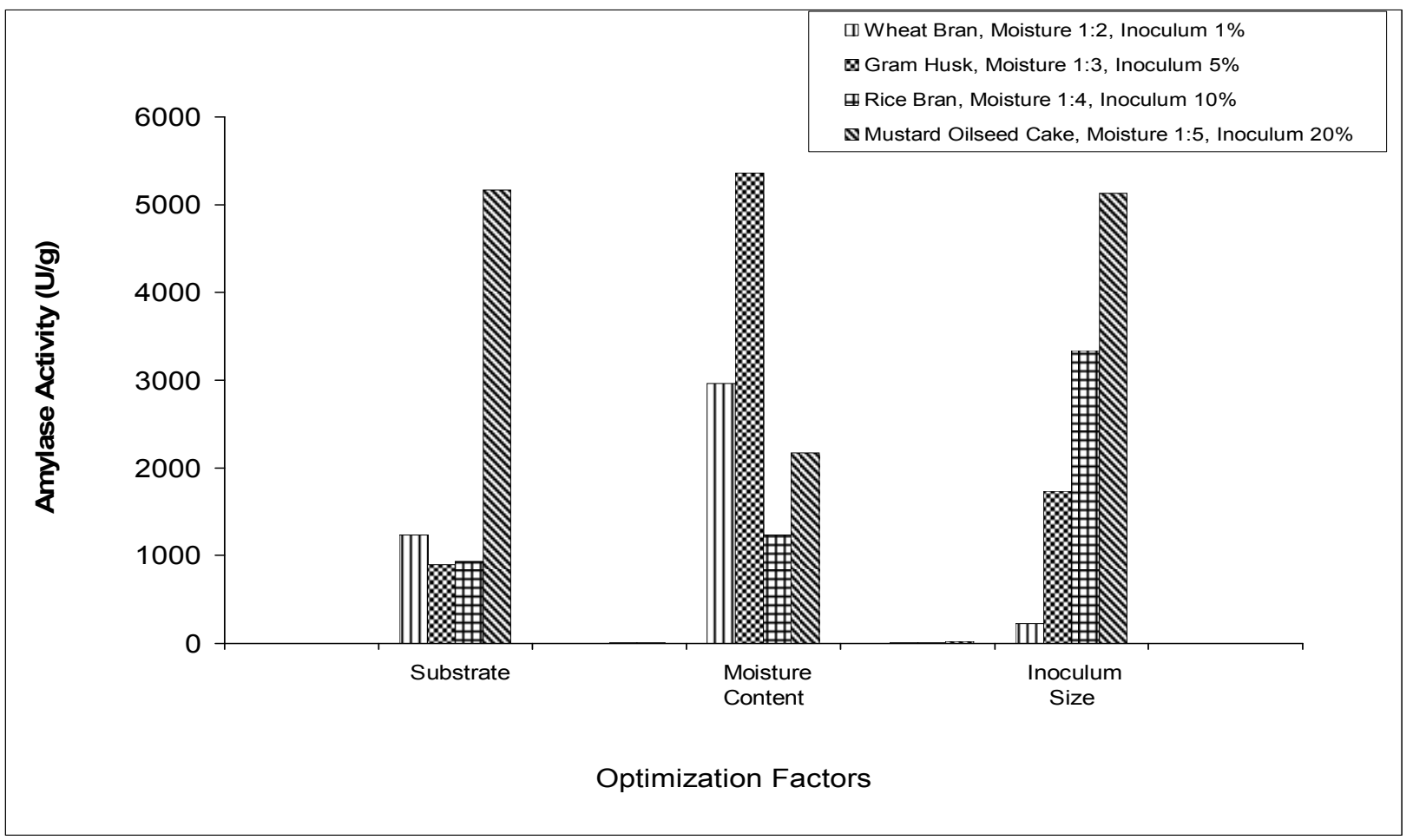

Figure 2. Effect of variation in Substrate, Moisture Content and Inoculum Size in enzyme production

(四)- Substrate Wheat Bran, Moisture Content 1:2, Inoculum Size 1\%,

(図) - Substrate Gram Husk, Moisture Content 1:3, Inoculum Size 5\%,

(買) - Substrate Rice Bran, Moisture Content 1:4, Inoculum Size 10\%,

$(\mathbb{\mathbb { }})$ - Substrate Mustard Oilseed Cake Moisture Content 1:5, Inoculum Size 20\%,

\section{Optimum Temperature and $\mathrm{pH}$}

Fig. 3(a) shows the activity of the enzyme at different temperatures ranging from $30^{\circ} \mathrm{C}$ to $70^{\circ} \mathrm{C}$. The Optimum temperature was found to be $50^{\circ} \mathrm{C}$. Fig. 3(b) shows the activity of the enzyme at different $\mathrm{pH}$ ranging from 5 to 9 . The Optimum $\mathrm{pH}$ was found to be 6 .

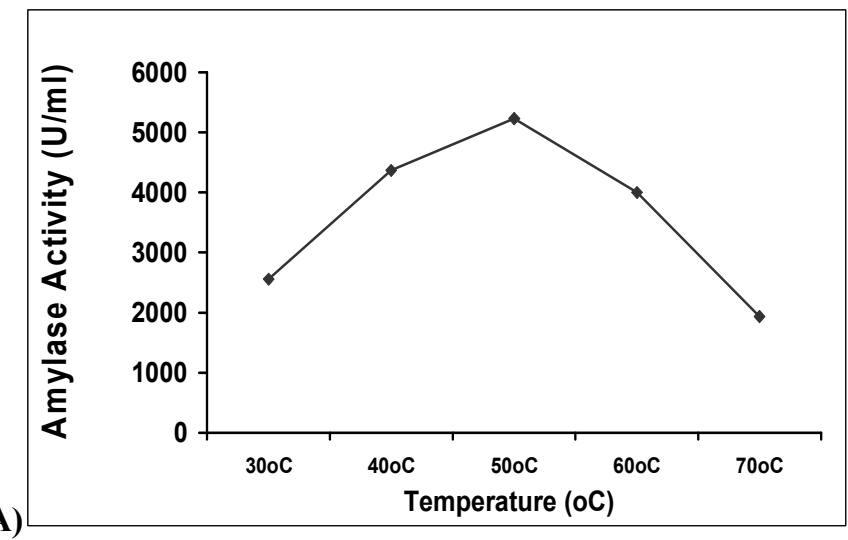

A)

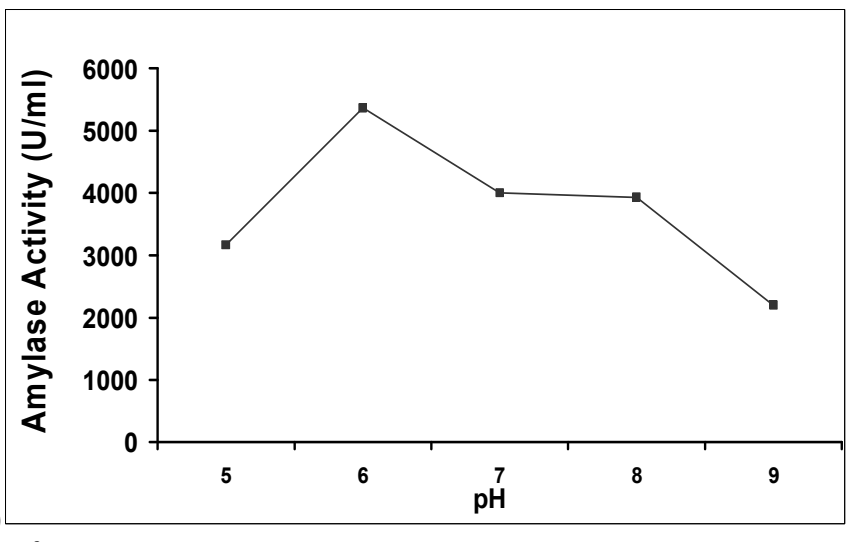

B) $70^{\circ} \mathrm{C}$ ]. (b): $\mathrm{pH}$ optimization for enzyme production [5 to 9]
๓Wheat Bran, Moisture 1:2, Inoculum 1\%

$\boxplus$ Rice Bran, Moisture 1:4, Inoculum 10\%

\$ Mustard Oilseed Cake, Moisture 1:5, Inoculum 20\% 


\section{Thermostability and pH stability of the enzyme}

Fig. 4(a) represents the stability of the enzyme at various temperatures. The enzyme was found to be stable at $30^{\circ} \mathrm{C}$ for $2 \mathrm{~h}$. At 40 and $50^{\circ} \mathrm{C}$ the enzyme was stable for $1 \mathrm{~h}$, thereafter retaining $90 \%$ of its activity. At 60 and $70^{\circ} \mathrm{C}$ the enzyme retained $75-80 \%$ of its activity after $2 \mathrm{~h}$.

Fig. 4(b) represents the stability of the enzyme at different $\mathrm{pH}$. The enzyme was very stable at neutral $\mathrm{pH}$ (6- 7). At $\mathrm{pH} 5$ the enzyme showed stability for $1 \mathrm{~h}$, thereafter losing only about $20 \%$ activity. At pH 8 and 9 it lost about $50 \%$ of its activity in $30 \mathrm{~min}$.

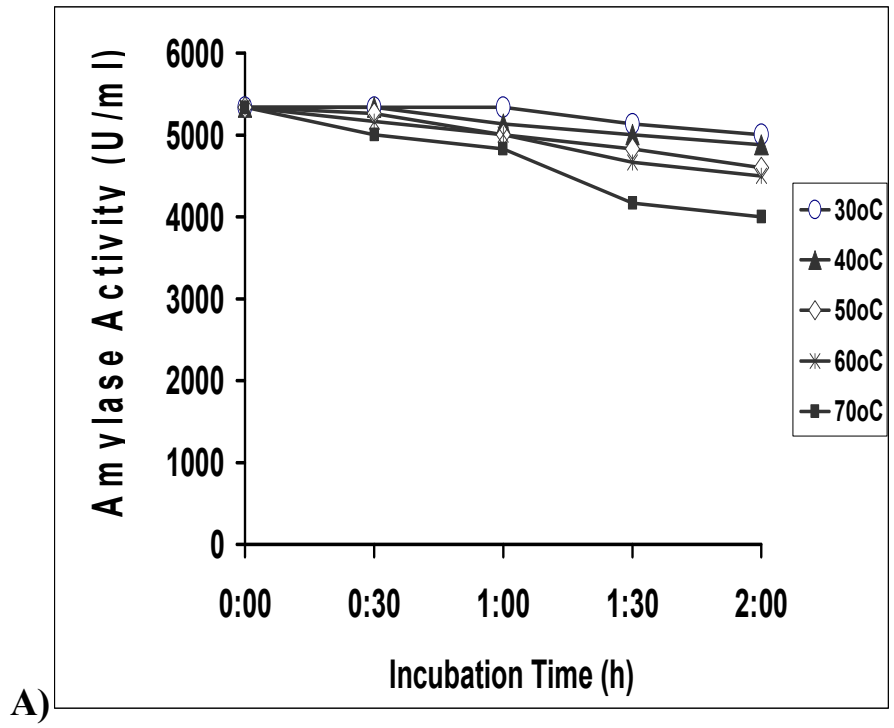

Figure 4. (a): Stability of enzyme at temperatures $30^{\circ} \mathrm{c}$ to $70^{\circ} \mathrm{C}$

\section{Effect of Metal Ions}

The presence of salts as $\mathrm{Ca}^{2+}, \mathrm{Mg}^{2+}, \mathrm{Co}^{2+}$ and $\mathrm{Na}^{+}$at $5 \mathrm{mM}$ concentration enhanced the activity of the enzyme (Table 1). Addition of $10 \mathrm{mM} \mathrm{CaCl}$ increased the activity of the enzyme two fold, and retained $50 \%$ of the activity after $1 \frac{1}{2} \mathrm{~h}$ and decreasing further in $2 \mathrm{~h}$ at $70^{\circ} \mathrm{C}$. However, at $5 \mathrm{mM} \mathrm{CaCl} \mathrm{CaC}_{2}$ the activity of the enzyme enhanced by $30 \%$ and retained more than $90 \%$ of its activity in $2 \mathrm{~h}$ (Fig. 5). In contrast, $\mathrm{CoCl}_{2}$ and $\mathrm{NaCl}$ reduced the amylase activity at $10 \mathrm{mM}$ (Table 1).

Table 1. Effect of various metal ions on enzyme activity

\begin{tabular}{|c|c|c|c|c|}
\hline Salt Concentration & $\mathrm{Ca}^{++}$ & $\mathbf{M g}^{++}$ & $\mathrm{Co}^{++}$ & $\mathrm{Na}^{+}$ \\
\hline Without Salt & $5166^{*}$ & $5166^{*}$ & $5166^{*}$ & $5166^{*}$ \\
\hline $5 \mathrm{mM}$ & 8500 & 6000 & 6166 & 7500 \\
\hline $10 \mathrm{mM}$ & 10666 & 3500 & 5000 & 5666 \\
\hline
\end{tabular}




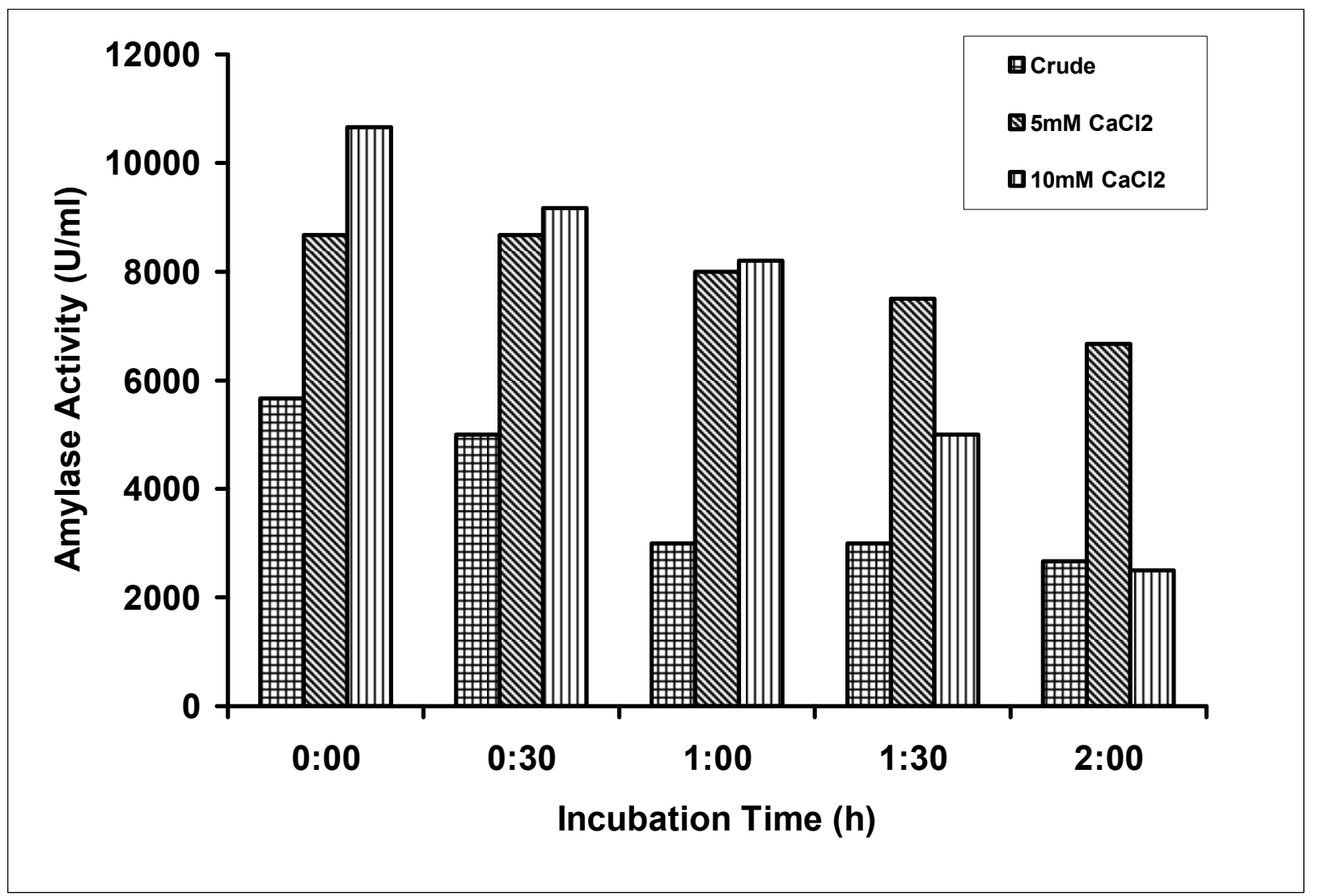

Figure 5. Effect of $\mathrm{Ca}^{++}$ions on the thermal stability of the enzyme at $70^{\circ} \mathrm{C}$
(㖆) - Crude,
$(\mathbb{\mathbb { }})-5 \mathrm{Mm} \mathrm{CaCl}_{2}$
(四) $-10 \mathrm{mM} \mathrm{CaCl}_{2}$

\section{DISCUSSION}

The isolated strain exhibited a large zone of clearance in the starch test which showed that it was able to produce amylase in a substantial quantity. From the industrial viewpoint it is necessary to have a strain that can produce large quantity of the enzyme in short fermentation time. Our strain produced very high amount of amylase, about $5400 \mathrm{U} / \mathrm{g}$ in only $72 \mathrm{~h}$ which is much higher than that reported by other researchers in SSF $(14,24)$

Moisture content is a critical factor for SSF processes because this variable has influence on growth and biosynthesis and secretion of different metabolites. Lower moisture content causes reduction in solubility of the nutrients of the substrate, low degree of swelling and high water tension (4). On the other hand, higher moisture levels can cause a reduction in enzyme yield due to steric hindrance of the growth of strain by reduction in porosity (interparticle spaces) of the solid substrate, thus interfering with oxygen transfer (21). The moisture levels in SSF processes vary between 30 and 85\% (4). The optimum moisture content for growth and substrate utilization depends on the organism and the substrate used for cultivation. In this study the optimum moisture content for the enzyme production was found to be $33 \%$.

Inoculum size is an important factor for the production of enzyme. Lower inoculum level results in a lower number of cells in the production medium. This requires a longer time to grow to an optimum number to utilize the substrate and form the desired product (13). The best inoculum size in our study was $20 \%$.Bayasl et al (2008) have also reported $20 \%$ inoculum 
size as optimum in SSF of wheat bran in amylase production, though Anto et al. (2006), have reported that increase in inoculum size adversely affected the enzyme production.

It is evident from this study that oilseed cakes may serve as ideal fermentation bases for obtaining high yields of amylase from Bacillus sp. Mustard oilseed cake contains a lower level of proteinaceous matter and a higher level of carbohydrate than all the other substrates used (16), thus is a suitable nutrient source by itself for amylase production. However, Ikram-ul-Haq et al. (2003) have reported wheat bran as the best substrate for $\alpha$-amylase production by Bacillus licheniformis using different agricultural by-products.

Amylases are known to be active in a wide range of temperature $\left(40-90^{\circ} \mathrm{C}\right)$ and $\mathrm{pH}(4-11)$. The optimum temperature of this amylase was $50^{\circ} \mathrm{C}$, which is similar to that described for other Bacillus amylases $(15,7)$. This identifies the unique characteristic of this Bacillus sp that grows at $37^{\circ} \mathrm{C}$ as a mesophile, but the enzyme it produces is active and stable at high temperatures $\left(50-70^{\circ} \mathrm{C}\right)$. Similar finding has been reported by Hagihara et al. (2006). The stability of the enzyme was found to be independent of divalent calcium ions. The enzyme stability trend, as reported in the present study, agrees with the behavior of amylases from Bacillus sp. investigated by Cordeiro et al. (2002). Thermal stabilization of the enzyme in the presence of calcium has also been reported (8).

The $\mathrm{pH}$ optima of the enzyme was found to be 6 with stability in range 5-7. Amylases are active and stable over a wide range of $\mathrm{pH}(3.5-12),(15,7)$, though some are only stable within a narrow $\mathrm{pH}$ range (9).

The enzyme activity was found to be enhanced by lower concentrations of calcium, cobalt, magnesium and sodium ions. Similar findings have been reported by Ajayi and Fagade (1), However their reports of $\mathrm{NaCl}$ being less effective for enzyme activity contradicts our study where $\mathrm{NaCl}$ has been found to enhance the activity, equally.

The unique capability of amylase to retain about $80 \%$ enzyme activity at $70{ }^{\circ} \mathrm{C}$ compared to the optimum at $50^{\circ} \mathrm{C}$ makes it useful for various industrial applications like starch liquefaction at increased temperature as starch liquefaction is carried out at higher temperatures of $70-90 \quad{ }^{\circ} \mathrm{C} \quad$ (3). Furthermore, the enzyme was active under acidic to neutral condition ( $\mathrm{pH}$ 6-7), which facilitates its use in dough preparation in the food industry, juice and fruit processing, baking and brewing industry.

\section{REFERENCES}

1. Ajayi, A.O.; Fagade, O.E. (2003). Utilization of corn starch as substrate for $\beta$ - amylase by Bacillus spp. African Journal of Biomedical Research, 6(1), 37-42.

2. Aneja, K.R. (2002). Experiments in Microbiology, Plant Pathology, Tissue culture and Mushroom Production Technology. New Age International (P). Ltd Publishers, New Delhi, India, Pp169 -171.

3. Anto, H.; Trivedi, U.; Patel, K. (2006). Alpha Amylase Production by Bacillus cereus MTCC 1305 Using Solid-State Fermentation. Food Technol. Biotechnol. 44 (2), 241-245.

4. Balkan, B.; Ertan, F. (2007). Production of $\alpha$-Amylase from $P$. chrysogenum, under SSF by using some agricultural by-products. Food Technol. Biotechnol. 45 (4), 439-442.

5. Baysal, Z.; Uyar, F.; Aytekin, C. (2003). Solid state fermentation for production of $\alpha$-amylase by a thermotolerant $B$. subtilis from hot-spring water. Process Biochem. 38, 1665-1668.

6. Baysal, Z.; Uyar, F.; Dogru, M.; Alkan, H. (2008). Production of extracellular alkaline $\alpha$ Amylase by SSF with a newly isolated Bacillus sp. Prep. Biochem. Biotechnol. 38, 184-190.

7. Bernhardsdotter, E.C.M.J.; Ng. J.D.; Garriott, O.K.; Pusey, M.L. (2005). Enzymic properties of an alkaline chelator-resistant $\alpha$ amylase from an alkaliphilic Bacillus sp. isolate L1711. Process Biochem. 40, 2401-2408.

8. Chung, Y.C.; Kobayashi, T.; Kanai, H.; Akiba, T.; Kudo, T. (1995). Purification and properties of extracellular amylase from the hyperthermophilic Archaeon Thermococcus profundus DT 5432. Appl Environ Microbiol. 61(4): 1502 -1506

9. Coronado, M.; Vargas. C.; Hofemeister, J.; Ventosa, A.; Nieto, J.J. (2000). Production and biochemical characterization of an $\alpha$ amylase from the moderate halophile Halomonas meridiana. FEMS Microbiol. Lett. 183, $67-71$.

10. Hagihara, H.; Igarashi, K.; Hayashi, Y.; Endo, K.; Ikawa-Kitayama, K.; Ozaki, K.; Kawai, S.; Ho, S. (2001). Novel $\alpha$ amylase that is highly resistant to chelating reagents and chemical oxidants from the alkaliphilic Bacillus isolate KSM.K.38. Appl. Environ. Microbiol. 67, 1744-1750. 
11. Ikram-ul-Haq, H.; Ashraf, J.; Iqbal, M.A.; Qadeer. (2003). Production of alpha amylase by Bacillus licheniformis using an economical medium. Bioresour. Technol. 87, 57 - 61.

12. Kathiresan, K.; Manivannan, S. (2006). a Amylase production by Penicillium fellutanum isolated from mangrove rhizosphere soil. African J. Biotech. 5 (10), 829-832.

13. Kashyap, P.; Sabu, A.; Pandey, A.; Szakas, G.; Soccol, C.R. (2002). Extracellular L-glutaminase production by Zygosaccharomyces rouxii under SSF. Process. Biochem. 38, 307-312.

14. Kokab, S.; Ashgar, M.; Rehman, K.; Asad, M.J.; Aedeyo, O. (2003). Bio-Processing of banana peel for $\alpha$-Amylase production by $B$. subtilis. Internat. J Agric Biol. 1560-8530, 36-39.

15. Konsula, Z.; Liakopoulou-Kyriakides, M. (2004). Hydrolysis of starches by the action of an $\alpha$ amylase from Bacillus subtilis. Process Biochem. 39, 1745-1749.

16. Krishnan, T.; Chandra, A.K. (1982). Effect of Oilseed Cakes on $\alpha$ Amylase Production by Bacillus licheniformis CUMC 305. Appl. Environ. Microbiol. 44: 270-274.

17. Kunamneni, A.; Perumal, K.; Singh, S. (2005). Amylase production in solid state fermentation by the thermophilic fungus Thermomyces Lanuginosus. J. Biosci. Bioeng. 100(2): 168 - 171

18. Miller, G.L. (1959). Use of Dinitro salicylic acid reagent for determination of reducing sugar. Analytical Chemistry, 31, 426 - 429.

19. Pandey, A.; Nigam, P.; Soccol, C.R.; Soccol, V.T.; Singh, D.; Mohan, R. (2000). Advances in microbial amylases. Biotechnol. Appl. Biochem. 31:135-152.

20. Pandey A; Soccol C.R; Rodriguez-Leon, J.A.; Nigam, P. (2001). Solidstate fermentation in biotechnology, Fundamentals and Applications. 1st edition. pp $8-29$.

21. Perez-Guarre, N.; Torrado-Agrasar, A.; Lopez-Macias, C.; Pastrana, L. (2003). Main characteristics and application of solid substrate fermentation, Electron. J. Environ. Agric. Food Chem., 2, 243-350.

22. Ramachandran, S.; Patel, A.K.; Nampoothiri, K.M.; Chandran, S.; Szakacs, G.; Soccol, C.R.; Pandey, A. (2004). Alpha amylase from a fungal culture grown on oil cakes and its properties. Braz. Arch. Biol. Technol. 47, 309-317.

23. Sodhi, H.K.; Sharma, K.; Gupta, J.K; Soni, S.K., (2005). Production of a thermostable $\alpha$ amylase from Bacillius sp. PS-7 by solid state fermentation and its synergistic use in the hydrolysis of malt starch for alcohol production. Process Biochem. 40, 525-534

24. Varalakshmi, K.N.; Kumudini, B.S.; Nandini, B.N.; Solomon, J.D.; Mahesh, B.; Suhas, R.; Kavitha, A.P. (2008). Characterization of Alpha Amylase from Bacillus sp.1/isolated from paddy seeds. J Appl Biosci, $1(2), 46-53$. 